\title{
Rethinking Redeemability: One Hundred Years of Rosenzweig's Star of Redemption
}

One hundred years have passed since the J. Kauffmann Jüdischer Buchverlag published Franz Rosenzweig's The Star of Redemption, arguably the single most significant work of Jewish philosophy written in the twentieth century. Rosenzweig had "scribbled this book down ... in a six-month-long exstasis"1 between August 1918 and February 1919. Beginning shortly after he recovered from the respiratory flu that swept Europe that summer, Rosenzweig wrote through the last months of his service on the Balkan front of the German war effort and through the first months of his return to civilian life in Kassel. Through the collapse of the German monarchy and Germany's devastating loss in the war itself, and through a series of attempted revolutions between November 1918 and January 1919, Rosenzweig wrote, completing The Star on February 16, 1919, only days after Friedrich Ebert was elected the first president of the German Republic in Weimar. By the time The Star was published, in January 1921, Rosenzweig had relocated from Kassel to Frankfurt in order to take up the directorship of the Freies Jüdisches Lehrhaus, a context in which he would seek to revolutionize postemancipatory adult Jewish education, and from out of which grew the great translation projects of his later years.

Rosenzweig's writings of the 1920 s show that for all the differences among the various projects he took on after completing The Star, he remained oriented through them all by the horizon of the Star itself, that is to say, by the concept of redemption. According to Rosenzweig, redemption designates that future point of unity towards which all beings strive through acts of interpersonal love and recognition, through the formation of religious and political communities, and - as highlighted in Rosenzweig's post-Star projects - through translation; it is a future point that orients our everyday temporal existence but that we can experience proleptically through liturgical practice; a future point toward which history unfolds, without history thereby achieving it.

The Star as a whole takes up the monumental task of articulating the systematic unity of all beings - "the All," as Rosenzweig calls it - and it presents this "All" as a unity to be forged out of the relations between three elemental kinds

1 Franz Rosenzweig to Eduard Strauß, October 26, 1919, in Franz Rosenzweig, Der Mensch und sein Werk: Briefe und Tagebücher II: 1918-1929 (Haag: Martinus Nijhoff, 1979), 649. 
of beings: God, world, and selves. On Rosenzweig's account, every being strives to attain a kind of stable, holistic balance between substantiality and agency (what Rosenzweig terms "factuality"). But for reasons Rosenzweig spells out in the Star, individual beings cannot fully actualize themselves, they cannot attain to such a stability of being without entering into relations with others. This is the case no less for God than it is for human beings and the world. As the culmination of the course of the interrelation of all beings, redemption marks for Rosenzweig that ultimate future moment in which all beings will have united through relations to form "the All."

While every individual being is needful of redemption, in the Star, insofar as it cannot attain to the completion of its own being without entering into reciprocal relations with others, every individual being is at once redeemable: capable of entering into those relations that lead to such redemptive completion. But the ultimate recipient of redemption, the ultimate subject who will be the unity of all being in the redemptive future, is God alone. The reciprocal relations between God, world, and human beings - or more precisely, the interrelations between human beings and the world that are initiated through God's turning first into relation with the world and with the human being, respectively - aim ultimately at God's own redemption. Rosenzweig writes that "in the redemption of the world through the human being, of the human being by the world, God redeems Himself."

At least this is how redemption is supposed to unfold. It turns out, however, that things aren't quite so simple. Rosenzweig is well aware of how many individuals fail to recognize their need for relations of love and reciprocal respect and instead seek out self-fulfillment divorced from others; of how many individuals fail to invest what is required for healthy mutuality and instead forge destructive or self-undermining relationships; of how many communities are built on force rather than on reciprocity. Until redemption will be actual, its actualization remains dependent on the right kind of relationships being forged between individual beings; and according to Rosenzweig every failed relationship courts a collapse of the envisioned happy ending, quite literally, into "nothing." Moreover, forging a redemptive unity out of all beings takes such unfathomable coordination - the coordination of all natural, political, cultural, and spiritual life - that Rosenzweig openly questions how we can be certain that worldly redemption, human redemption, and divine redemption actually refer to the same ultimate future event. Rosenzweig's answer is that Jewish and Christian life, and in particular the course of the Jewish and Christian liturgical calendars, in which God, world, and human beings are envisioned as attaining

2 Franz Rosenzweig, Der Stern der Erlösung (Frankfurt: Suhrkamp, 1988), 266. 
a proleptic relational unity, amount to "guarantees" - something less than a proof but more than a probability - that the ultimate redemption will be such as to allow for the unified but also distinct self-fulfillments of divine, worldly, and human beings.

This special issue takes the fragility, the uncertainty, and even the questionability of Rosenzweig's concept of redemption as the starting point for reflection. To mark the one hundredth anniversary of the publication of the Star, we have invited eleven internationally renowned scholars to reflect on the theme of redeemability from a range of disciplinary and theological perspectives: religious studies, Christian theology, Islamic studies, German language and literature, political science, philosophy, and Jewish thought. Is the world redeemable? Is the human being redeemable? Is God redeemable? Each scholar has been asked to address one of these three quintessentially Rosenzweigian questions directly and invited to take her or his lead from Rosenzweig's own thinking about redemption (we did not request that contributors write about Rosenzweig, although many authors did so). Our aim is not only to bring a variety of historically extant views about redemption and redeemability into conversation with one another, but also to pose questions of redeemability for readers today. Is it meaningful to conceive of the world, the human being, or God as redeemable today? And if so, should we conceive of the world, the human being, and/or God as redeemable? What are the conditions for constructing a discourse of redemption that is coherent or tenable or humane? What is it that makes so much redemption-talk destructive? In what ways is our thinking enriched, and in what ways is our thinking endangered by the concept of redemption?

In responding to the question, "Is the world redeemable?" Irene Kajon, Paul Mendes-Flohr, Mohammad Khalil, and Julie Cooper take up broadly theological-political concerns. Across their different disciplinary and theological perspectives, their responses share a common interest in evaluating the consequences of utopian or apocalyptic views of redemption, and in articulating an alternative view that we might call a mundane or humanizing account of redemption. In "Anarchic Cosmopolitanism and Nation States in Franz Rosenzweig's Messianism," Irene Kajon contrasts the redemptive prophecy of the biblical Isaiah with the political realism of Machiavelli and suggests that Rosenzweig's Star offers an account of the world's redemption that combines virtues of these opposed positions. According to Kajon, the Star develops a view of politics as oriented by ethics while not losing sight of the historical contingencies and all-too-human, utilitarian positioning of this-worldly political experience, and this view inspired an important line of Jewish political thinking - through such late twentieth-century figures as 
Emmanuel Levinas and André Neher - that continues to this day. In "Contra Redemption," Paul Mendes-Flohr provocatively asserts that the world today is most desperately in need of redemption from visions of redemption themselves. Mendes-Flohr is especially wary of the consequences of the secularization of messianism in nationalist political movements like Zionism. He finds in Rosenzweig's rooting of redemption in acts of loving-kindness a kind of modest and humane alternative to grand visions of redemption, one that he suggests Rosenzweig shares with literary figures like Anton Chekhov and Vassily Grossman. Taking his lead from Rosenzweig's attribution of an undifferentiated universalism to Islam, Mohammad Khalil presents a range of Sunni approaches to the question of the redeemability of non-Muslims in his "Islam and the Possibility of World Redemption." Khalil is most interested in exploring Muslim theologians who ground the possibility of the salvation of those who do not accept Islam either in divine mercy or in the temporality of hell, and suggests that there is an important link between such universalizing views of redemption and the humanization of the other within the everyday worldly context. In her "Ge'ulah versus Pidyon: Toward a Mundane, Non-Eschatological Approach to Redemption," Julie Cooper reflects not primarily on the dangers of messianic politics, but precisely on the dangers of a form of political inaction that finds justification in the fear of messianic politics. Contemporary Israeli politics suffers from what Cooper terms a ge'ulah complex - a paralysis caused by the mistaken view that the only form of redemptive politics possible is straightaway apocalyptic. In the place of the eschatologically driven politics of geulah, Cooper advocates a more mundane redemptive politics of pidyon, which finds theological, but distinctly non-messianic grounds for a release from unjust states of affairs.

What is remarkable across the responses to the question of the redeemability of the world is the surprising proximity in which they stand to one another, given the very different disciplinary and theological perspectives out of which they were written. In contrast, the responses to the question, "Is the human being redeemable?" penned by Agata Bielik-Robson, Hans-Martin Dober, Vivian Liska, Ari Salamah-Qudsi, and Elliot R. Wolfson are striking precisely for the sharp differences they convey both regarding how redemption itself is to be understood and regarding how Rosenzweig's account of redemption is to be judged. Agata Bielik-Robson's “A Meditation on Rosenzweig's Claim That Death Is Very Good" locates in Rosenzweig's thought a Jewish account of finitude as quintessentially redeemable. Such redeemability-in-the-finite is precisely not a promise of complete redemption, but rather an ever-present redemptive potentiality in human life, never to be fully realized. As such, it articulates a compelling view of personal existence, according to Bielik-Robson, to be 
distinguished both from traditional accounts of the soul's immortality, on the one hand, and from a death-oriented philosophical understanding of human finitude, on the other. Drawing upon Hans Blumenberg's philosophical anthropology, Hans-Martin Dober presents "Consolation as an Integral Meaning of Rosenzweig's Understanding of Redemption: A Blumenbergian Reflection." Placing Rosenzweig into fruitful theological conversation with Martin Luther, Dober highlights the redemptive-cum-consolatory aspects of especially nonconceptual forms of human understanding, exploring a range of both subjective and intersubjective practices, such as repentance from sin and prayer for forgiveness, recollection and dialogue, but also music and humor. Vivian Liska's "A Self-Defeating Question" responds to the question of human redeemability by suggesting that our question rashly presumes a positive answer to the more important question as to whether the human being should be redeemed, i.e., whether redemption is a good for which human beings should hope or strive. Liska is troubled by what she views as the absolute, totalizing form redemption takes in the Star, and by what the human being would have to give up in order to attain such a form of redemption: her very humanity. We might say Liska is troubled because she understands Rosenzweig to promote a view of redemption that is quite at odds with the view that Bielik-Robson attributes to him. In contrast, Liska advocates a position with respect to redemption that she finds in the writings of Walter Benjamin and Franz Kafka - and perhaps in Rosenzweig's own later essay, "The Builders," which finds redemption in fleeting and fragmentary form as a messianic dimension that breaks into (and out of) human, historical existence, while at once deferring into infinity any notion of redemption as a final end. Is this proposed alternative to Rosenzweig the very position Bielik-Robson finds in the Star itself? The way in which redemption may be conceived as breaking into this-worldly, historical time, rather than (merely) as a world-to-come, likewise stands as the focus of Arin Salamah-Qudsi's "The Redemption of the Human Being in Islamic Tradition: The Sufi Perspective." Highlighting the centrality of the cultivation of devotional sincerity in the Sufi path to unification with the divine, Salamah-Qudsi traces intricacies of the dialectic of human and divine action in the Sufi view of spiritual redemption that are lost in Rosenzweig's own flattened account of divine love in Islamic theology. In tracing the Sufi account of spiritual redemption as both total liberation from the worldly, but at once as momentary, and thus as eventuating in the return of the Suf practitioner back into a worldly life replete with responsibilities for self, community, and world, Salamah-Qudsi shows Sufi engagement with the theme of redemption to be rich in the very kinds of questions about the relations among the worldly, the human, and the divine that Rosenzweig takes up in the Star. In "Rosenzweig on 
Human Redemption: Neither Nothing Nor Everything, But Only Something," the article that closes this section on human redeemability, Elliot R. Wolfson questions what he calls "overly optimistic" readings of the Star, which take solace in the possibility of an anticipation of redemption within time. Wolfson's reflections spell out, to the contrary, how readily Rosenzweig's position entails a hopelessness regarding redemption in history, on the one hand, and at once flirts with a commitment to a final, suprahistorical redemption that swallows up all temporal life, on the other. In sharp contrast to Bielik-Robson's account of Rosenzweig as identifying the possibility of redemption within finitude, then, Wolfson sees Rosenzweig's position as collapsing either into a finitude without redemption, or a redemption without finitude. As such, he views Rosenzweig's thought as leading to the very forms of nihilism and gnosticism that Rosenzweig found troubling when they stood before him in the figure of a young Gerhard Scholem. At the same time, in drawing our attention to points at which Rosenzweig describes redemption not as the end of historical time but rather as the breaking of eternity into history and, as a consequence, as celebrating "worldlessness as the most appropriate way to experience being in the world," Wolfson brings Rosenzweig's account of redemption into proximity to the very views of Benjamin and Kafka that Liska advocates in Rosenzweig's stead.

"Is God redeemable?" is the question that Hans-Christoph Askani and Paul Franks address in the issue's final section. Askani opens his reflections by suggesting that we are so inclined to hope for redemption by God that the very question of God's own redeemability is disorienting, and even appears blasphemous. But Askani concludes that God's need for redemption in fact follows from any attempt to take seriously the thought that governs the Star as a whole, to wit, that God initiates living relationships of love and dialogical encounter with the world and human beings in it. The vitality of these relationships demands that God be thought as implicated in the mutual relationship between human beings and the world and in what they realize in their mutual interdependency: the shared expression of the affirmative recognition of divine goodness, the very goodness that creation brought to life in the world. Franks's "Redeeming God, Redeeming Redemption" concludes the issue by doubling down on the provocative presupposition of the question. Without a robust conception of God as both the subject and the object of redemption, Franks argues, the very term "redemption" remains open to such misunderstanding and misuse that it should be abandoned altogether. Such a conception is to be found in the Star, and Franks traces Rosenzweig's view back to rabbinic and kabbalistic sources. Franks suggests, on the one hand, that only 
a view of God as the object of redemption can respond to the threat of nihilism that has plagued German philosophy since Jacobi, but also, on the other hand, that only if human redemptive acts are to be viewed as contributing to an ultimately divine act of redemption can human beings be saved from an equally threatening hubris that has had devastating effects in the shape of redemptive politics.

The eleven contributors to the issue thus address an array of conceptions of redemption and take up the relationships Rosenzweig asserts as holding between the world, the human being, and the divine - and what it would mean for each to be redeemable - in different, often opposing ways. Alongside differences in discipline among contributors, our contributors have also taken Rosenzweig's unique position on redemption as a springboard for reflections on notions of redemption that emerge from the traditions of Jewish theology, of Christian theology, and of Islamic theology. Rosenzweig's account of Islam in the Star is among the book's most troubling features. Recent literature on Rosenzweig and Islam has aptly criticized Rosenzweig's views, often situating them in the context of early twentieth-century German orientalism. ${ }^{3}$ The two articles devoted to Islam in this issue advance the discourse on Rosenzweig and Islam rather by bringing Rosenzweig's account of redemption into theological conversation with diverse views of redemption within Islamic theology, in which redemption is explored, respectively, as a spiritual experience attainable within time and as the condition that will define the end of days.

The articles collected here are largely based on responses to the questions raised regarding worldly, human, and divine redeemability at a February 2019 conference in Jerusalem of the Internationale Rosenzweig Gesellschaft, "Back to Redemption: Rosenzweig's Star 1919-2019," organized by the Franz Rosenzweig Minerva Research Center, with generous support from a number of foundations and grants, most prominently the Loewe-RelPos grant at Goethe University, and the Minerva Foundation. ${ }^{4}$

3 See, inter alia, Robert Erlewine, "Fire, Rays, and the Dark: Rosenzweig and the Oriental/ Occidental Divide," in Judaism and the West: From Hermann Cohen to Joseph Soloveitchik (Bloomington: Indiana University Press, 2016), 52-77; and Gesina Palmer, "Einleitung," and Yossef Schwartz, "Die entfremdete Nähe: Rosenzweigs Blick auf den Islam," in "Innerlich bleibt die Welt eine”: Ausgewählte Texte von Franz Rosenzweig über den Islam, ed. Y. Schwartz and G. Palmer (Berlin: Philo, 2003), 9-32, 113-147.

4 This publication is part of the LOEwE research hub "Religious Positioning: Modalities and Constellations in Jewish, Christian and Muslim Contexts" at the Goethe University Frankfurt and the Justus-Liebig-University in Giessen, funded by the Hessian Ministry of Science and Art. 
Our hope is that the myriad reflections prompted by the questions we've raised regarding redeemability, in marking the one hundredth anniversary of the publication of Rosenzweig's The Star of Redemption, will encourage philosophical and theological thinking about the meaning, the importance, and the limits of the notion of redemption in our time and into the future.

Benjamin Pollock

The Hebrew University, Jerusalem, Israel

benjamin.pollock@mail.huji.ac.il 